(c) American Dairy Science Association, 2003.

\title{
Kinetics of In Sacco Fiber-Attachment of Representative Ruminal Cellulolytic Bacteria Monitored by Competitive PCR
}

\author{
S. Koike, J. Pan, Y. Kobayashi, and K. Tanaka \\ Graduate School of Agriculture, Hokkaido University, Sapporo 060-8589, Japan
}

\begin{abstract}
Stems of orchardgrass hay in nylon bags were incubated in the rumens of three ruminally fistulated sheep to monitor the rate and extent of fiber attachment by the representative ruminal cellulolytic bacteria via competitive polymerase chain reaction. After incubation for $5 \mathrm{~min}$, the numbers of Fibrobacter succinogenes and the two ruminococcal species attached to stems were $10^{5}$ and $10^{4} / \mathrm{g}$ dry matter (DM) of stem, respectively. At $10 \mathrm{~min}$, the numbers of all three species attached to stems increased 10-fold. Thereafter, attached cell numbers of the three species gradually increased and peaked at $24 \mathrm{~h}\left(10^{9} / \mathrm{g} \mathrm{DM}\right.$ for $F$. succinogenes and $10^{7} / \mathrm{g} \mathrm{DM}$ for Ruminococcus flavefaciens) or $48 \mathrm{~h} \mathrm{(10} 6 \mathrm{~g} \mathrm{DM}$ for Ruminococcus albus). On the other hand, cell numbers of all three species in the whole digesta were constant over $24 \mathrm{~h}$. Changes in the rate of in sacco neutral detergent fiber disappearance of hay stem, which showed a linear increase up to $96 \mathrm{~h}$, were not synchronized with changes in cellulolytic bacterial mass. These results suggest that sufficient numbers of cells of the three cellulolytic species to move to new plant fragments are present at the start of incubation, the initial attachment to new plant matter is mostly accomplished within $10 \mathrm{~min}$ and then bacterial growth and fibrolytic action follow. $F$. succinogenes was most dominant, both in the whole rumen digesta and on the suspended hay stems, demonstrating the ecological and functional significance of this species in ruminal fiber digestion.
\end{abstract}

(Key words: fiber attachment, ruminal cellulolytic bacteria, competitive PCR)

\section{INTRODUCTION}

Ruminant animals are able to use plant fiber primarily composed of cellulose and xylan as an energy source because of a symbiotic relationship with microbes (bac-

Received August 29, 2002

Accepted October 20, 2002

Corresponding author: Dr. Yasuo Kobayashi; e-mail: kyas@anim. agr.hokudai.ac.jp. teria, fungi and protozoa) in the rumen. Of the rumen microbes, bacteria and fungi produce a wide range of highly active plant cell-wall degrading enzymes, and their contribution to fiber digestion is estimated to be $80 \%$ of total activity (Dijkstra and Tamminga, 1995). Although rumen fungi possess superior ability such as penetration of plant cell wall and solubilization of lignin, their contribution to fiber digestion might be low, due to small biomass ( $8 \%$ of total microbial mass) (Orpin and Joblin, 1997). Ruminal bacteria play a particularly important role in the biological degradation of dietary fiber because of their much larger biomass. Bacteria inhabiting the rumen have been classified into four groups depending on their environmental existence: 1) free-living bacteria associated with rumen liquid phase; 2) bacteria associated with feed particles; 3) bacteria associated with rumen epithelium; and 4) bacteria attached to the surface of protozoa (Czerkawski and Cheng, 1988; McAllister et al., 1994). Bacterial populations associated with feed particles (group 2) are numerically predominant and account for up to $75 \%$ of the total microbial population (Minato et al., 1993). Furthermore, microbial populations associated with feed particles are estimated to be responsible for $80 \%$ of total rumen endoglucanase activity (Minato et al., 1966). These data indicate that fiber-associated populations are pivotal for ruminal fiber digestion. Because attachment is an essential step for fibrolytic bacteria to initiate digestion of dietary fiber in the rumen, numerous investigations have explored various aspects of bacterial attachment to feed particles.

Fibrobacter succinogenes, Ruminococcus flavefaciens and Ruminococcus albus are considered to be representative cellulolytic bacteria of the rumen (Forsberg et al., 1997). The abilities of these three species to attach to plant fibers and the mechanisms of this attachment have been studied using pure cultures (Minato and Suto, 1978; Mosoni et al., 1997; Pegden et al., 1998) and their digestive activities have been visualized by electron microscopy (Latham et al., 1978; Cheng et al., 1980; 1981). Mosoni et al. (1997) reported that attachment of $R$. flavefaciens and $F$. succinogenes peaked after $45 \mathrm{~min}$ of contact with limited cellulose. Latham et al. (1978) demonstrated that $F$. succinogenes and $R$. 
flavefaciens each have specific attachment sites on perennial ryegrass in vitro; $F$. succinogenes was predominant on the cut edges of mesophyll cell walls and the intact faces of mesophyll, while $R$. flavefaciens was predominant on the cut edges of epidermal cell walls. Although numerous important findings were obtained from these in vitro studies, it is difficult to track specific bacterial species quantitatively in vivo using traditional enumeration techniques such as culturing. Quantitative confirmation of the rate and extent of fiber attachment in vivo is necessary in order to estimate the contribution of the three representative cellulolytic species to ruminal fiber digestion. We recently developed competitive PCR (cPCR) assays that facilitate the rapid and accurate enumeration of $F$. succinogenes, $R$. flavefaciens and $R$. albus without the need for culturing (Koike and Kobayashi, 2001). Application of these assays to the analysis of fiber-associated populations could provide quantitative information on these species in vivo. Moreover, such analysis may confirm which species plays the largest role in ruminal plant fiber digestion.

In the present study, we sequentially monitored the in vivo abundance and in sacco fiber-associated populations of $F$. succinogenes, $R$. flavefaciens and $R$. albus using cPCR assays to evaluate the rate and extent of fiber attachment in the rumen.

\section{MATERIALS AND METHODS}

\section{Animals and Feeding}

Three ruminally fistulated wethers (average body weight, $89.0 \mathrm{~kg})$ were fed orchardgrass hay $(1.5 \mathrm{~kg}$ once/ day at $0900 ; \mathrm{CP}, 11.6 \%$; NDF, $68.2 \%$ ) cut to lengths of $2 \mathrm{~cm}$. Sheep were allowed to eat for $2 \mathrm{~h}$ and then the remaining feed (average, $0.2 \mathrm{~kg}$ ) was removed. All sheep were kept individually indoors and were allowed continuous access to mineralized salt and water. A 3 wk adaptation period was followed by the 8 wk experimental period, during which in sacco incubation and ruminal sampling was conducted.

\section{In Sacco Incubation and Ruminal Sampling}

Two nylon bags $(7 \times 15 \mathrm{~cm}$; pore size $=50 \mu \mathrm{m})$ containing chopped stems of orchardgrass hay (length, 2 $\mathrm{cm} ; 5 \mathrm{~g} / \mathrm{bag}$ ) were placed into the rumen of each sheep immediately prior to feeding. Bags were removed from the rumen at 5, 10, 60, $120 \mathrm{~min}, 6,14,24,48$ and 96 $\mathrm{h}$. After removal from the rumen, bags were rinsed in water $\left(38^{\circ} \mathrm{C}\right)$ until it ran clear, and then squeezed by hand to remove excess water. One bag from each set was immediately frozen to be used for quantitative analysis of fiber-attached bacterial populations by
cPCR, and the other bag was dried at $60^{\circ} \mathrm{C}$ for $48 \mathrm{~h}$. Residue remaining in the dried bags was employed for measurement of NDF disappearance (Goering and Van Soest, 1970).

Rumen digesta were mixed by hand, and representative samples were collected, without separation of liquid and solids, immediately before feeding and at 2, 6, 14 and $24 \mathrm{~h}$ after feeding. Sampling at each time point was carried out on different days with intervals of at least $4 \mathrm{~d}$ in order to minimize possible effects of hand mixing on the rumen environment. Samples were placed in 50-ml polypropylene tubes and stored at $-80^{\circ} \mathrm{C}$ until used for bacterial quantitation.

\section{Enumeration of Representative Ruminal Cellulolytic Bacteria}

Cell numbers of the representative ruminal cellulolytic bacteria ( $F$. succinogenes, $R$. flavefaciens and $R$. albus) both on hay stems and in whole rumen digesta were enumerated by cPCR assay as described by Koike and Kobayashi (2001). Essential protocol is described below.

Total DNA extraction from stems incubated in sacco and rumen digesta was conducted as described by Purdy et al. (1996). Each sample (0.35 g) was mixed with $0.35 \mathrm{ml}$ of TE buffer ( $\mathrm{pH} \mathrm{8.0)}$ ) and $0.7 \mathrm{ml}$ of Trisbuffered phenol ( $\mathrm{pH}$ 8.0) in a 2-ml tube containing 0.25 $\mathrm{g}$ of glass beads (diameter, 425 to $600 \mu \mathrm{m}$; Sigma Chemical, St Louis, MO). After adding $40 \mu \mathrm{l}$ of $10 \%$ SDS, the tubes were shaken three times for $2 \mathrm{~min}$ with $2 \mathrm{~min}$ of incubation on ice between shakings. Tubes were centrifuged at $16,000 \times g$ for $5 \mathrm{~min}$. The supernatant was purified with hydroxyapatite chromatography (Hydroxyapatite Bio-Gel HTP Gel, Bio-Rad, Hercules, CA) followed by gel filtration (MicroSpin S-200 HR Columns, Amersham Pharmacia Biotech, Piscataway, NJ). Purified DNA was fluorescently quantified (DyNA Quant 200, Hoefer Pharmacia Biotech, San Francisco, CA) and subjected to PCR.

Competitive PCR was conducted using the following 16S rDNA-targeted species specific primer sets: S-SFsucc-0219-a-S-18 (5'-GGTATGGGATGAGCTTGC-3') and S-S-Fsucc-0654-a-A-18 (5'-GCCTGCCCCTGAACTATC-3') targeting $F$. succinogenes; S-S-Rfl-0154-a-S17 (5'-TCTGGAAACGGATGGTA-3') and S-S-Rfl-0425a-A-22 (5'-CCTTTAAGACAGGAGTTTACAA-3') targeting $R$. flavefaciens; and S-S-Ral-1281-a-S-22 (5'CCCTAAAAGCAGTCTTAGTTCG-3') and S-S-Ral1439-a-A-19 (5'-CCTCCTTGCGGTTAGAACA-3') targeting $R$. albus (Wang et al., 1997; Koike and Kobayashi, 2001). PCR was performed with AmpliTaq Gold (PE Applied Biosystems, Foster City, CA) for hot start and time release PCR. PCR conditions for F. succino- 


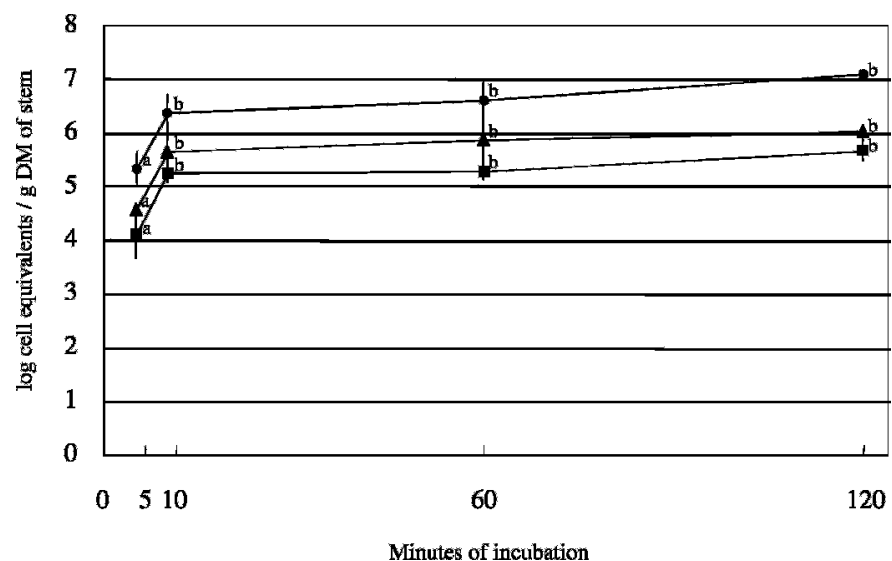

Figure 1. Time course of in situ incubated fiber-associated cell numbers of Fibrobacter succinogenes (-), Ruminococcus flavefaciens $(\checkmark)$ and Ruminococcus albus (ם) within 120 min incubation. ${ }^{\text {ab }}$ Means within the species with different superscripts differ $(P<0.05)$.

genes were as follows: $30 \mathrm{~s}$ at $94^{\circ} \mathrm{C}$ for denaturing, 30 $\mathrm{s}$ at $60^{\circ} \mathrm{C}$ for annealing and $30 \mathrm{~s}$ at $72^{\circ} \mathrm{C}$ for extension (48 cycles), except for 9 min denaturation in the first cycle and $10 \mathrm{~min}$ extension in the last cycle. Amplification of $16 \mathrm{~S}$ rDNA for the two ruminococcal species was carried out similarly except the annealing temperature was $55^{\circ} \mathrm{C}$. Products of cPCR were separated on agarose gel, stained with ethidium bromide, and photographed. Band intensities were quantified using image analysis software (NIH image 1.57, National Institutes of Health) to determine the amount of target in the initial samples. All cPCR assay values were converted into cell equivalents using standard curves for each bacterial species prepared using pure cultures.

\section{Calculation and Statistics}

Changes in bacterial cell number on stems incubated in sacco between sampling periods were converted to increase rates using the following equation as described by Fields et al. (2000): dx/dt $=\ln \mathrm{N}-\ln \mathrm{N} 0=\mu \mathrm{t}$ where $\mathrm{x}$ is cell mass, $\mathrm{t}$ is time, $\mathrm{N} 0$ is the initial cell number, $\mathrm{N}$ is the cell number after a specified time, and $\mu$ is the specific increase rate constant. Increase rates were expressed as fold/h.

Cellulolytic bacterial cell numbers on hay stems and in the rumen were analyzed for effects of time and bacterial species using the GLM procedure of SAS. Comparisons between means were performed using Tukey's $t$ test at a significance level of 0.05 .

\section{RESULTS AND DISCUSSION}

Changes in the attached cell populations of the three cellulolytic species over the first $2 \mathrm{~h}$ are shown in Figure 1. After 5 min of incubation, the populations of $F$. succi- nogenes and the two ruminococcal species attached to the stems were $10^{5}$ and $10^{4} / \mathrm{g} \mathrm{DM}$, respectively. Because none of the three species were detected on non-incubated stem (data not shown), all of these attached cells were considered to have originated in the rumen. The number of attached cells for all three species then increased $(P<0.05) 10$ fold by $10 \mathrm{~min}$ of incubation. This rapid increase over the first 10 min suggests that large numbers of cellulolytic bacteria are poised for attachment to new plant particles entering the rumen. The present in sacco quantitative data confirm that the three cellulolytic species rapidly attach to plant fiber in the rumen, as previously demonstrated in in vitro studies using mono- or di-culture of specific strain(s) (Mosoni et al., 1997; Roger et al., 1990). Roger et al. (1990) reported that $R$. flavefaciens attached to cellulose within 1 min of first contact whereas $F$. succinogenes required $30 \mathrm{~min}$, thus suggesting the superiority of Ruminococcus spp. to $F$. succinogenes with regard to initial fiber attachment. Other studies also demonstrated competition among the three cellulolytic species in vitro using cellulose as a substrate (Odenyo et al., 1994; Shi et al., 1997). When plant fiber such as barley straw or perennial ryegrass was used for substrate, differences in binding and colonization sites were observed between $F$. succinogenes and $R$. flavefaciens in vitro (Latham et al., 1978; Bhat et al., 1990). In the present study, no obvious competition was observed among the three species, which all showed similar rates of attachment in sacco (Figure 1). This suggests that there are no considerable antagonistic interactions between the three cellulolytic species during the initial attachment to plant fiber or the subsequent period of growth. To the best of our knowledge, the present in sacco study is the first to report equal rates of attachment among the three species, which disagrees with earlier in vitro results showing different attachment rates and sites in each species (Latham et al., 1978; Bhat et al., 1990; Roger et al., 1990). Our in sacco results may reflect the actual ruminal situation rather than in vitro results, because studies using bacterial cultures lack selection by protozoal predation, stronger competition between greater numbers of bacteria and outflow from the rumen. However, even in sacco nylon bag technique has been argued about its suitability, because microbial access to the feed in the bag is limited by various factors including a pore size. Although we used a nylon bag with recommended pore size $(50 \mu \mathrm{m})$ (Meyer and Mackie, 1986), caution must be paid for further interpretation. For instance, non motile cellulolytic bacterium such as $F$. succinogenes could be under estimated, since such bacterium is supposed to enter into a bag more slowly (Meyer and Mackie, 1986). 


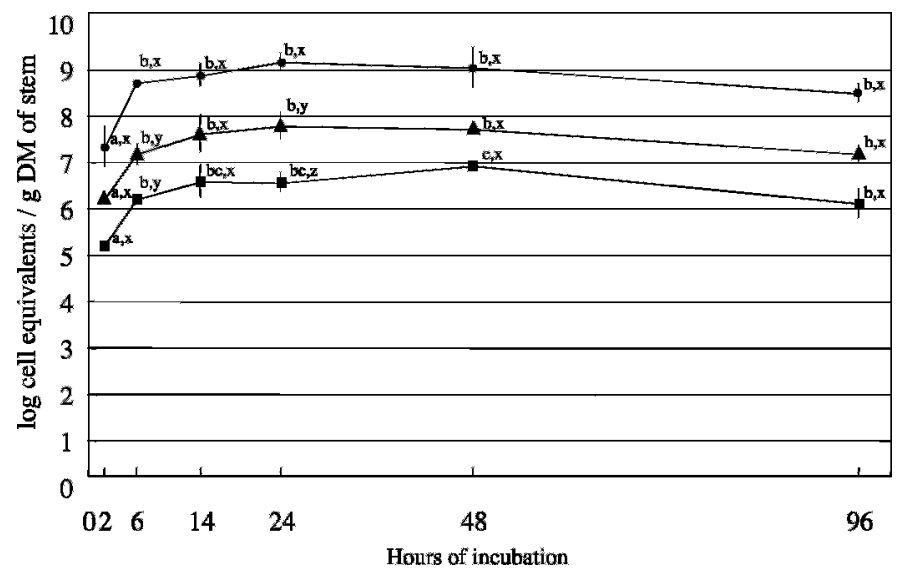

Figure 2. Time course of in situ incubated fiber-associated cell

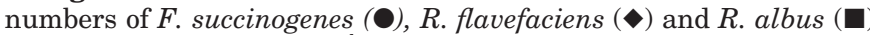
from 2 to $96 \mathrm{~h}$ incubation. ${ }^{\text {abc }}$ Means within the bacterial species with different superscripts differ $(P<0.05)$. ${ }^{\mathrm{xyz}}$ Means among the bacterial species with different superscripts differ $(P<0.05)$.

Changes in attached cell numbers of the three cellulolytic species between 2 and $96 \mathrm{~h}$ are shown in Figure 2 . A steady increase in the number of attached cells was observed for all the three species until $6 \mathrm{~h}$ of incubation (Figure 2, Table 1). There are two explanations of the increased cell populations on the incubated stems; one is the attachment of new bacteria from the liquid phase or other particles, and the other is cell proliferation on the stems. Although we cannot clearly identify the individual contributions of each mechanism, cell proliferation seems to be more reasonable as an explanation for the increased cell populations since cell number on the stems showed exponential increase up to $6 \mathrm{~h}$ after rapid increase within $10 \mathrm{~min}$. Furthermore, microcolony formation on plant fiber by Fibrobacter- and Ruminococcus-like bacteria was observed in previous studies (Cheng et al., 1980; 1981). These suggest that the increase in attached cell numbers observed in present study can be mostly attributed to cell proliferation on the stem. From $6 \mathrm{~h}$, the numbers of attached cells of the three species gradually increased and peaked at 24 h $\left(10^{9} / \mathrm{g}\right.$ DM for $F$. succinogenes and $10^{7} / \mathrm{g}$ DM for $R$. flavefaciens) or $48 \mathrm{~h}\left(10^{6} / \mathrm{g} \mathrm{DM}\right.$ for R. albus) (Figure 2). At $96 \mathrm{~h}$, the associated population sizes for all three

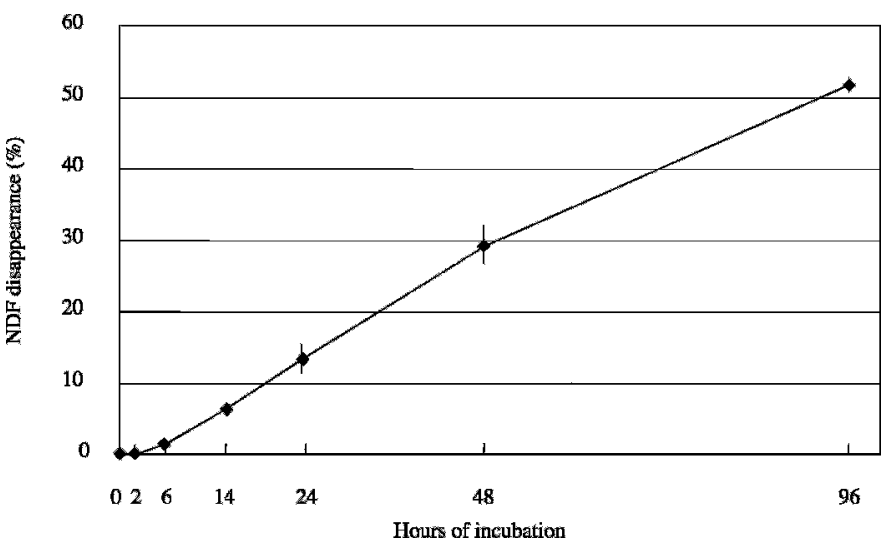

Figure 3. NDF disappearance of stems of orchardgrass hay during in situ incubation for $96 \mathrm{~h}$.

species had decreased to $20 \%$ of the respective maximum levels. The extent of bacterial attachment was different for each of the three species $(P<0.05)$ and the hay stem was invaded primarily by $F$. succinogenes.

$\mathrm{NDF}$ of stems incubated in sacco disappeared continuously through $96 \mathrm{~h}$ as shown in Figure 3. This was not synchronized with changes in cell numbers of the three cellulolytic bacteria attached to the stem (Figure 2). Bowman and Firkins (1993) reported that changes in particle-associated bacterial mass and NDF disappearance are not coincidental during in sacco ruminal incubation. They suggested the possibility that fiberattached bacteria utilized other substrates, such as soluble carbohydrate, before starting NDF digestion. Furthermore, in vitro studies have demonstrated that fibrolytic enzyme secretion is induced by cellulose or xylan substrates after several hours of incubation (Malburg et al., 1997; Bera et al., 1999; Flint et al., 1999), resulting in corresponding delays in fiber digestion. Therefore, active production of fibrolytic enzymes in cellulolytic bacteria may occur after consuming soluble substrate that facilitates bacterial growth on the plant fiber. These reports partly explain the fact that changes in stem-attached cell numbers of cellulolytic bacterial species were not synchronized with NDF disappearance. Another possible explanation is based on characteristics of fiber degrading system of the moni-

Table 1. Increase rate between sampling periods for three cellulolytic bacteria on in situ incubated stem.

\begin{tabular}{|c|c|c|c|c|c|c|c|c|}
\hline \multirow[b]{2}{*}{ Bacteria } & \multicolumn{8}{|c|}{ Increase rate $($ fold $/ \mathrm{h})$} \\
\hline & $5-10 \min$ & $10-60 \mathrm{~min}$ & $60-120 \min$ & $2-6 \mathrm{~h}$ & $6-14 \mathrm{~h}$ & $14-24 \mathrm{~h}$ & $24-48 \mathrm{~h}$ & $48-96 h$ \\
\hline F. succinogenes & $10^{12 \mathrm{a}}$ & $1.98^{\mathrm{b}}$ & $3.00^{\mathrm{b}}$ & $2.22^{\mathrm{b}}$ & $1.05^{\mathrm{b}}$ & $1.07^{\mathrm{b}}$ & $0.99^{b}$ & $0.97^{\mathrm{b}}$ \\
\hline$R$. albus & $10^{14 \mathrm{a}}$ & $1.05^{\mathrm{b}}$ & $2.42^{\mathrm{b}}$ & $1.78^{\mathrm{b}}$ & $1.12^{\mathrm{b}}$ & $0.99^{b}$ & $1.03^{\mathrm{b}}$ & $0.96^{\mathrm{b}}$ \\
\hline
\end{tabular}

${ }^{\mathrm{a}, \mathrm{b}, \mathrm{c}}$ Means within the bacterial species with different superscripts $\operatorname{differ}(P<0.05)$. 
tored species. These three species degrade plant fiber by secreted and cell surface-bound fibrolytic enzymes which bind to the substrate to degrade it (McGavin et al., 1990; Mosoni and Gaillard-Martinie, 2001). Therefore, fiber degradation could be continued by these fibrolytic enzymes even after cell death, which might cause the asynchronism between NDF disappearance and the cellulolytic bacterial mass. However, these results must be considered carefully because fiber was not only digested by these three cellulolytic species, but also by other fibrolytic bacteria and non-fibrolytic/ fibrolysis-aiding bacteria (Stanton and Canale-Parola, 1980; Fondevila and Dehority, 1996; Rychlik and May, 2000).

The increase rate of attached cell populations for the three cellulolytic species is calculated and presented in Table 1. Over the first $10 \mathrm{~min}$, the number of attached cells increased more rapidly than at later time periods $(P<0.05)$. Although a slight but nonsignificant difference was observed in the increase rates among the three species within $120 \mathrm{~min}$, the subsequent increase rate was almost identical (1.75 to $2.22 \mathrm{fold} / \mathrm{h}, P>0.05$ ) up to $6 \mathrm{~h}$ of incubation. Miron et al. (2001) divided the process of fiber attachment of $F$. succinogenes, $R$. flavefaciens and $R$. albus into four phases: 1 , transport of nonmotile bacteria onto the substrate; 2 , initial nonspecific attachment of bacteria to unprotected sites on the substrate; 3 , specific attachment to the substrate via adhesins or ligands; and 4, proliferation of attached bacteria on potentially digestible substrate tissues. They also suggested that the manufacture of adhesins and ligands are induced during initial cell wall polysaccharide digestion, and that this process requires several hours. Therefore, the extremely high increase rate observed in the first 10 min suggests that the first two phases (transport and nonspecific attachment) were completed within $10 \mathrm{~min}$ of inserting the hay stems into the rumen.

The rate and extent of fiber attachment by the three cellulolytic species may have been underestimated in the present in sacco study because the effects of mastication were ignored. Feed particles ingested by ruminant animals are re-chewed via rumination and this process increases the surface area of such particles. The newly generated and considerably damaged surfaces are potential attachment sites for bacteria, and this may accelerate bacterial attachment to the plant fiber as well as subsequent fiber digestion (Pan et al., accepted). Therefore, changes in bacterial population size on feed particles in vivo might be more dynamic than those observed in our in sacco studies.

Population sizes of the three cellulolytic species in the whole rumen digesta were constant over $24 \mathrm{~h}$ (Figure 4). This observation agrees with Briesacher et al. (1992),

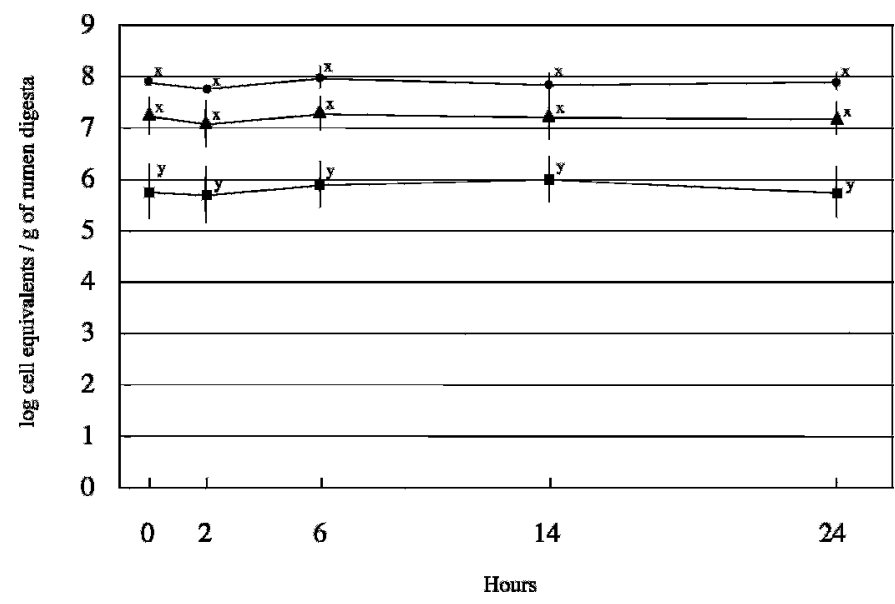

Figure 4. Diurnal changes of population sizes for $F$. succinogenes $(\bullet), R$. flavefaciens ( ) and R. albus ( $\square$ ) in the rumen of sheep. ${ }^{\mathrm{xy}}$ Means among the bacterial species with different superscripts differ $(P<0.05)$.

who reported that there were no differences in population size of $F$. succinogenes with time after feeding or between solid and liquid phases in steer rumen. In addition, Fields et al. (2000) demonstrated that although undigested and attachable surface remained on the cellulose, daughter cells of $F$. succinogenes on the colonized cellulose became free in the medium. Therefore, some of the daughter cells of fiber-attached bacteria may be released from the particles and become attached to new particles. This may be one of the reasons why these cellulolytic bacteria were able to maintain their population size in the rumen. The rapid attachment to stems observed in the present study (Figure 1) demonstrates the existence of a large number of "ready to attach" cells in the rumen, including both free-suspended and fiber-associated cells.

Of the three monitored species, $F$. succinogenes was the most dominant $(P<0.05)$ both in whole rumen digesta and on hay stem suspended in the rumen (Figures 1, 2 and 4). These results were in agreement with our previous reports, where cell numbers of $F$. succinogenes in sheep rumen were greater than those of the two Ruminococcus species, irrespective of dietary conditions (Koike and Kobayashi, 2001). Michalet-Doreau et al. demonstrated that $F$. succinogenes had larger rumen populations than those of $R$. flavefaciens and $R$. albus in sheep on both a roughage diet (2001) and on a highgrain diet (2002). Tajima et al. (2001) suggested that $F$. succinogenes population levels reach at least the same levels as $R$. flavefaciens in dairy cows using real-time PCR. All of these studies indicate the ecological and functional significance of $F$. succinogenes among the known species of fiber digesters. In contrast, Weimer et al. (1999) revealed that the population of $R$. albus 
was much greater than that of either $R$. flavefaciens or $F$. succinogenes in dairy cows. However, they simultaneously pointed out large variations of these cellulolytic species between animals, suggesting the complexity of community structure. The diversity and existence of numerous uncultured rumen bacteria were also demonstrated by $16 \mathrm{~S}$ rDNA sequencing (Whitford et al., 1998; Tajima et al., 1999; 2000). Therefore, further investigations including uncultured bacteria may be necessary. As partially shown in the present study, molecular analysis of ecology (community structure) and physiology (enzyme production and nutrient requirements) of fibrolytic microbial consortia could be more effective when we consider strategies for optimization of fiber digestion in ruminants.

In conclusion, we demonstrated the kinetics of in sacco fiber attachment to hay stems by the representative ruminal cellulolytic bacteria $F$. succinogenes, $R$. flavefaciens and $R$. albus using quantitative data. Fiber attachment occurs at an equal rate in these three bacterial species and is primarily achieved within $10 \mathrm{~min}$. Subsequent growth may continue for up to 24 or $48 \mathrm{~h}$. The extent of bacterial association with the hay stem was greatest for $F$. succinogenes, followed by $R$. flavefaciens and $R$. albus, reflecting the abundance of each species in whole rumen digesta. NDF disappearance of the incubated hay stem increased linearly up to $96 \mathrm{~h}$, and was not synchronized with changes in bacterial mass on the stem. This is probably due to the delayed increase in fibrolytic activities.

\section{REFERENCES}

Bera, C., G. Gaudet, and E. Forano. 1999. Regulation of glycosylhydrolase genes expression in Fibrobacter succinogenes S85. Pages 541-544 in Genetics, Biochemistry and Ecology of Cellulose Degradation. Ohmiya K, et al., eds., Uni Publishers, Co. Ltd., Tokyo, Japan.

Bhat, S., R. J. Wallace, and E. R. Ørskov. 1990. Adhesion of cellulolytic ruminal bacteria to barley straw. Appl. Environ. Microbiol. 56:2698-2703.

Bowman, J. G. P., and J. L. Firkins. 1993. Effects of forage species and particles size on bacterial cellulolytic activity and colonization in situ. J. Anim. Sci. 71:1623-1633.

Briesacher, S. L., T. May, K. N. Grigsby, M. S. Kerley, R. V. Anthony, and J. A. Paterson. 1992. Use of DNA probes to monitor nutritional effects on ruminal prokaryotes and Fibrobacter succinogenes S85. J. Anim. Sci. 70:289-295.

Cheng, K.-J., J. P. Fay, R. E. Howarth, and J. W. Costerton. 1980. Sequence of events in the digestion of fresh legume leaves by rumen bacteria. Appl. Environ. Microbiol. 40:613-625.

Cheng, K.-J., J. P. Fay, R. N. Coleman, L. P. Milligan, and J. W. Costerton. 1981. Formation of bacterial microcolonies on feed particles in the rumen. Appl. Environ. Microbiol. 41:298-305.

Czerkawski, J. W., and K.-J. Cheng. 1988. Compartmentation in the rumen. Pages 361-385 in The Rumen Microbial Ecosystem. P. N. Hobson ed. Elsevier Science Publishing, New York.

Dijkstra, B. J., and S. Tamminga. 1995. Simulation of the effects of diet on the contribution of rumen protozoa to degradation of fibre in the rumen. Br. J. Nutr. 74:617-634.

Fields, M. W., S. Mallik, and J. B. Russell. 2000. Fibrobacter succinogenes S85 ferments ball-milled cellulose as fast as cellobiose until cellulose surface area is limiting. Appl. Microbiol. Biotechnol. 54:570-574.

Flint, H. J., V. Aurilia, J. Kirby, K. Miyazaki, M. T. Rincon-Torres, S. I. McCrea, and J. C. Martin. 1999. Organization of plant cell wall degrading enzymes in the ruminal anaerobic bacteria Ruminococcus flavefaciens and Prevotella bryantii. Pages 511-519 in Genetics, Biochemistry and Ecology of Cellulose Degradation. Ohmiya K, et al., eds, Uni Publishers, Co. Ltd., Tokyo, Japan.

Fondevila, M., and B. A. Dehority. 1996. Interaction between Fibrobacter succinogenes, Prevotella ruminicola, and Ruminococcus flavefaciens in the digestion of cellulose from forages. J. Anim. Sci. 74:678-684.

Forsberg, C. W., K.-J. Cheng, and B. A. White. 1997. Polysaccharide degradation in the rumen and large intestine. Pages 319-379 in Gastrointestinal Microbiology. R. I. Mackie and B. A. White, eds., Chapman and Hall, New York.

Goering, H. K., and P. J. Van Soest. 1970. Forage Fiber Analysis (Apparatus, Reagents, Procedure and Some Applications). Agrc. Handbook No. 379. ARS-USDA, Washington, DC.

Koike, S., and Y. Kobayashi. 2001. Development and use of competitive PCR assays for the rumen cellulolytic bacteria: Fibrobacter succinogenes, Ruminococcus albus and Ruminococcus flavefaciens. FEMS Microbiol. Lett. 204:361-366.

Latham, M. J., B. E. Brooker, G. L. Pettipher, and P. J. Harris. 1978. Adhesion of Bacteroides succinogenes in pure culture and in the presence of Ruminococcus flavefaciens to cell walls in leaves of perennial ryegrass (Lolium perenne). Appl. Environ. Microbiol. 35:1166-1173.

Malburg, S. R. C., L. M. Malburg, T. Liu, A. H. Iyo, and C. W. Forsberg. 1997. Catalytic properties of the cellulose-binding endoglucanase F from Fibrobacter succinogenes S85. Appl. Environ. Microbiol. 63:2449-2453.

McAllister, T. A., H. D. Bae, G. A. Jones, and K.-J. Cheng. 1994. Microbial attachment and feed digestion in the rumen. J. Anim. Sci. 72:3004-3018.

McGavin, M., J. Lam, and C. W. Forsberg. 1990. Regulation and distribution of Fibrobacter succinogenes subsp. succinogenes S85 endoglucanase. Appl. Environ. Microbiol. 56:1235-1244.

Meyer, J. H. F., and R. I. Mackie. 1986. Microbiological evaluation of the intraruminal in sacculus digestion technique. Appl. Environ. Microbiol. 51:622-629.

Michalet-Doreau, B., I. Fernandez, C. Peyron, L. Millet, and G. Fonty. 2001. Fibrolytic activities and cellulolytic bacterial community structure in the solid and liquid phases of rumen contents. Reprod. Nutr. Dev. 41:187-194.

Michalet-Doreau, B., I. Fernandez, and G. Fonty. 2002. A comparison of enzymatic and molecular approaches to characterize the cellulolytic microbial ecosystems of the rumen and the cecum. J. Anim. Sci. 80:790-796.

Minato, H., A. Endo, Y. Ootomo, and T. Uemura. 1966. Ecological treatise of the rumen fermentation. II. The amylolytic and cellulolytic activities of the fractionated bacterial portions attached to the rumen solids. J. Gen. Appl. Microbiol. 12:53-69.

Minato, H., and T. Suto. 1978. Technique for fractionation of bacteria in rumen microbial ecosystem. II. Attachment of bacteria isolated from bovine rumen to cellulose powder in vitro and elution of bacteria attached therefrom. J. Gen. Appl. Microbiol. 24:1-16.

Minato, H., M. Mitsumori, and K.-J. Cheng. 1993. Attachment of microorganisms to solid substrate in the rumen. Pages 139-145 in Genetics, Biochemistry and Ecology of Lignoellulose Degradation. Shimada, K., et al., eds., Uni Publishers, Co. Ltd., Tokyo, Japan.

Miron, J., D. Ben-Ghedalia, and M. Morrison. 2001. Adhesion mechanisms of rumen cellulolytic bacteria. J. Dairy Sci. 84:1294-1309.

Mosoni, P., G. Fonty, and P. Gouet. 1997. Competition between ruminal cellulolytic bacteria for adhesion to cellulose. Curr. Microbiol. 35:44-47.

Mosoni, P., and B. Gaillard-Martinie. 2001. Characterization of a spontaneous adhesion-defective mutant of Ruminococcus albus strain 20. Arch. Microbiol. 176:52-61.

Odenyo, A. A., R. I. Mackie, D. A. Stahl, and B. A. White. 1994. The use of $16 \mathrm{~S}$ rRNA-targeted oligonucleotide probes to study competition between ruminal fibrolytic bacteria: pure-culture 
studies with cellulose and alkaline peroxide-treated wheat straw. Appl. Environ. Microbiol. 60:3697-3703.

Orpin, C. G., and K. N. Joblin. 1997. The rumen anaerobic fungi. Pages 140-195 in The Rumen Microbial Ecosystem. P. N. Hobson and C. S. Stewart, Eds. Blackie Academic and Professional, Publishers, London.

Pan, J., S. Koike, T. Suzuki, K. Ueda, Y. Kobayashi, K. Tanaka, and M. Okubo. Effect of mastication on degradation of orchardgrass hay stem by rumen microbes: fibrolytic enzyme activities and microbe attachment. Anim. Feed Sci. Technol. accepted.

Pegden, R. S., M. A. Larson, R. J. Grant, and M. Morrison. 1998. Adherence of the Gram-positive bacterium Ruminococcus albus to cellulose and identification of a novel form of cellulose-binding protein which belongs to the Pil family of proteins. J. Bacteriol. 180:5921-5927.

Purdy, K. J., T. M. Embley, S. Takii, and D. B. Nedwell. 1996. Rapid extraction of DNA and rRNA from sediments by a novel hydroxyapatite spin-column method. Appl. Environ. Microbiol. 62:3905-3907.

Roger, V., G. Fonty, S. Komisarczuk-Bony, and P. Gouet. 1990. Effects of physicochemical factors on the adhesion to cellulose avicel of the ruminal bacteria Ruminococcus flavefaciens and Fibrobacter succinogenes subsp. succinogenes. Appl. Environ. Microbiol. 56:3081-3087.

Rychlik, J. L., and T. May. 2000. The effect of a methanogen, Methanobrevibacter smithii, on the growth rate, organic acid production, and specific ATP activity of three predominant ruminal cellulolytic bacteria. Curr. Microbiol. 40:176-180.
Shi, Y., C. L. Odt, and P. J. Weimer. 1997. Competition for cellulose among three predominant ruminal cellulolytic bacteria under substrate-excess and substrate-limited conditions. Appl. Environ. Microbiol. 63:734-742.

Stanton, B. A., and E. Canale-Parola. 1980. Treponema bryantii sp. nov., a rumen spirochete that interacts with cellulolytic bacteria. Arch. Microbiol. 127:145-156.

Tajima, K., R. I. Aminov, T. Nagamine, K. Ogata, M. Nakamura, H. Matsui, and Y. Benno. 1999. Rumen bacterial diversity as determined by sequence analysis of $16 \mathrm{~S}$ rDNA libraries. FEMS Microbiol. Ecol. 29:159-169.

Tajima, K., S. Arai, K. Ogata, T. Nagamine, H. Matsui, M. Nakamura, R. I. Aminov, and Y. Benno. 2000. Rumen bacterial community transition during adaptation to high-grain diet. Anaerobe. $6: 273-284$

Tajima, K., R. I. Aminov, T. Nagamine, H. Matsui, M. Nakamura, and Y. Benno. 2001. Diet-dependent shifts in the bacterial population of the rumen revealed with real-time PCR. Appl. Environ. Microbiol. 67:2766-2774.

Wang, R. F., W. W. Cao, and C. E. Cerniglia. 1997. PCR detection of Ruminococcus spp. in human and animal fecal samples. Mol. Cell. Probes. 11:259-265.

Weimer, P. J., G. C. Waghorn, C. L. Odt, and D. R. Mertens. 1999. Effect of diet on populations of three species of ruminal cellulolytic bacteria in lactating dairy cows. J.Dairy Sci. 82:122-134.

Whitford, F. M., R. J. Forster, C. E. Beard, J. Gong, and R. M. Teather. 1998. Phylogenetic analysis of rumen bacteria by comparative sequence analysis of cloned 16S rRNA genes. Anaerobe. 4:153163 